\title{
Bale quality and baler operational and economic performance as a function of working speeds and windrowed sugarcane trash volumes
}

\author{
Qualidade dos fardos, desempenho operacional e econômico de enfardadora em \\ função de velocidades de trabalho e volumes de palhiço de cana-de-açúcar enleirado
}

\author{
Tiago Pereira da Silva CORREIA ${ }^{1}$; Leandro Augusto Felix TAVARES ${ }^{2}$; \\ Anderson Ravanny de Andrade GOMES ${ }^{3}$; Paulo Roberto Arbex SILVA4; \\ Saulo Fernando Gomes de SOUSA ${ }^{5}$
}

\begin{abstract}
1 Autor para correspondência: Engenheiro Agronomo, Doutor em Agronomia, Universidade de Brasília, Faculdade de Agronomia e Medicina Veterinária - FAV/UnB, Campus Darcy Ribeiro, ICC sul, asa norte, Brasília/DF, Brasil. E-mail: tiagocorreia@unb.br

${ }^{2}$ Engenheiro Agrícola e Ambiental, Doutor em Agronomia, Universidade Federal dos Vales do Jequitinhonha e Mucuri, Campus Unaí, Unaí/MG. E-mail: leandro.tavares@ufvjm.edu.br

${ }^{3}$ Doutorando em Agronomia, Universidade Estadual Paulista "Julio de Mesquita Filho", Faculdade de Ciências Agronômicas, Botucatu/SP. E-mail: anderson_ravanny@hotmail.com

${ }^{4}$ Engenheiro Agronomo, Doutor em Agronomo, Universidade Estadual Paulista "Julio de Mesquita Filho", Faculdade de Ciências Agronômicas, Botucatu/SP. E-mail: arbex@fca.unesp.br

${ }^{5}$ Engenheiro Agronomo, Doutor em Agronomia, Agroefetiva, Botucatu/SP. E-mail: saulofgs@hotmail.com
\end{abstract}

Recebido em: 02-10-2018; Aceito em: 12-02-2019

\begin{abstract}
Energy cogeneration from sugarcane trash generally occurs through mechanical baling. This work evaluates the influence of baler speed and windrowed sugarcane trash volume on the operational, economic performance, and quality of prismatic bales produced by a baler. The experiment was carried out in a sugarcane production area, using a baler that produces rectangular prismatic bales, driven by a tractor with $161.81 \mathrm{~kW}$ nominal power. The experimental design was completely randomized in a $2 \times 2$ factorial scheme, consisting of two windrowed trash volumes (50 and 90\%) and two working speeds ( 3 and $5 \mathrm{~km} \mathrm{~h}^{-1}$ ), with six replicates. The following were evaluated: mineral impurity, dry weight, and volume of bales, as well as fuel consumption, operational capacity, costs, and economic efficiency of baling. Bale volume was not influenced by windrowed trash volume and baler speed. Higher windrowed trash volume provided lower cost per bale and higher mineral impurity index and dry weight of bales. Hourly fuel consumption, operational field capacity, and bale production increased with increasing speed. The highest economic efficiency is obtained with higher speed and windrowed trash volume.
\end{abstract}

Additional keywords: baling; fuel consumption; impurity; operating cost.

\section{Resumo}

O aproveitamento da palhiço de cana-de-açúcar para cogeração de energia é normalmente realizado a partir do enfardamento por máquinas. Objetivou-se neste trabalho avaliar a influência da velocidade de trabalho e o volume enleirado de palhiço de cana-de-açúcar no desempenho operacional, econômico e na qualidade dos fardos prismáticos produzidos por uma máquina enfardadora. $\mathrm{O}$ ensaio foi realizado em área de produção de cana-de-açúcar, sendo utilizada uma enfardadora de fardos prismáticos retangulares, tracionada por um trator com 161,81 kW de potência nominal. O delineamento experimental utilizado foi o inteiramente casualizado, em esquema fatorial $2 \times 2$, referente ao volume de palhiço enleirado (50 e 90\%) e à velocidade de trabalho (3 e $5 \mathrm{~km}$ $\mathrm{h}^{-1}$ ), com seis repetições. Avaliou-se a impureza mineral, a massa seca e o volume dos fardos, além do consumo de combustível, da capacidade operacional, dos custos e da eficiência econômica do enfardamento. O volume dos fardos não foi influenciado pelo volume de palhiço enleirado e pela velocidade da enfardadora. Maior volume de palhiço enleirado proporcionou menor custo por fardo, maior índice de impureza mineral e massa seca do mesmo. O consumo horário de combustível, a capacidade de campo operacional e a produção de fardos aumentaram com o incremento da velocidade. A maior eficiência econômica é obtida com maior velocidade e volume de palhiço enleirado.

Palavras-chave adicionais: consumo de combustível; custo operacional; enfardamento; impureza. 


\section{Introduction}

Sugarcane plant residues have been used as potential raw materials for energy purposes, being an alternative, renewable, and sustainable source (Marques \& Pinto, 2013). The rational use of this biomass represents an interesting solution for the technological advance in energy production, mainly in the vicinity of producing units (Santos et al., 2012).

Sugarcane biomass attracts attention because of its great potential in quantity and quality produced; however, it is still moderately exploited (Ferreira Filho \& Horridge, 2014). Even this being the case, the sector is growing, indicating an advance in plant biomass energy use in sugarcane producing areas (Steiner et al., 2011). According to MME/EPE (2017), 43.5\% of the Brazilian energy comes from renewable sources, of which sugarcane biomass accounts for only $17.5 \%$.

According to Ripoli \& Gamero (2007), sugarcane biomass, commonly known as sugarcane trash, is understood to be the plant material composed of green leaves, straw (dry leaves), tips, and stem fractions remaining on the ground. Franco et al. (2003) report that the amount of trash varies greatly after mechanized harvest, ranging from 4.7 to $22.8 \mathrm{t} \mathrm{ha}^{-1}$, depending on the planted variety, cane age, edaphoclimatic conditions, and harvest adjustments.

Some important agronomic aspects should be considered in trash recovery. The trash should not be totally extracted from the soil surface; its maintenance, at least in part, is directly related to soil microbial activities, favoring soil fertility and conservation (Franco, 2003). Moreover, total trash removal can modify soil physical properties, its water retention capacity, aeration, electrical conductivity, weed control, and agroecosystem productivity (Andreotti et al., 2015). According to the literature, removal of up to $50 \%$ of the trash from the soil does not impair physical, chemical, and biological aspects (Ripoli \& Gamero, 2007; UNICA, 2011).

Trash extraction for use in energy cogeneration is usually performed by balers. These machines collect and compact the trash, producing bales tied by sisal ropes, raffia, synthetic fabrics, wires, or twines (Guerra et al., 2013). For a better performance of balers, the trash is previously organized by a rake that gathers it by using the rotary movement of fingered discs to group the trash into windrows, which can be altered in size and biomass volume (Perea et al., 2012).

Balers are generally tractor driven and are graded according to the shape and size of the bales produced, with rectangular and cylindrical prism shapes being more common (Santos \& Borém, 2016). Bales can vary from low weight bales (with a few kilograms), enabling easy manual loading, to bales of over $700 \mathrm{~kg}$, with mechanized handling and transportation (Guerra et al., 2013).

Although studies and technological development have contributed to the improvement of trash baling, some obstacles still persist. Among these, we can highlight trash heterogeneity and low density, mineral impurity in bales produced, balers with low operational capacity and high costs (Michelazzo \& Braunbeck, 2008). Franco (2003) points out that the higher the working speed of the baler, associated with a larger windrowed trash volume, the greater the difficulty of collecting the material due to inadequate feeding rate of the machine platform. Baler jamming becomes thus more frequent, causing a greater number of stops for maintenance and consequently lower efficiency and operating capacity.

In this context, it is necessary to study the hypothesis of influence of working speed and windrowed sugarcane trash volume on the operational, economic performance, and quality of prismatic bales produced by a baler. Therefore, this study evaluates the performance of a baler and the quality of bales as a function of working speed and windrowed sugarcane trash volume.

\section{Materials and methods}

The experiment was carried out in a sugarcane producing area located in São Miguel dos Campos city, Alagoas State, with the following geographical coordinates: 9० 48' 24" S latitude, 36 6' 55" W longitude, and altitude of 97 meters. The climate of the region is classified as rainy tropical with dry summer, with annual rainfall of $1634.2 \mathrm{~mm}$ and average temperature between 34 and $24^{\circ} \mathrm{C}$. The soil is classified as dystrophic Yellow Latosol, typical of A clayey texture (Embrapa, 2013). The sugarcane variety grown in the experiment area was RB92579, planted in a spacing of one meter between rows.

The experimental design was completely randomized blocks with six replicates in a $2 \times 2$ factorial arrangement. Treatments consisted of two windrowed trash volumes (50 and 90\%) and two baler speeds (3 and $\left.5 \mathrm{~km} \mathrm{~h}^{-1}\right)$. They were identified as A1V1 (50\% windrowing and $3 \mathrm{~km} \mathrm{~h}^{-1}$ speed), A1V2 (50\% windrowing and $5 \mathrm{~km} \mathrm{~h}^{-1}$ speed), A2V1 (90\% windrowing and $3 \mathrm{~km} \mathrm{~h}^{-1}$ speed), and A2V2 (90\% windrowing and $5 \mathrm{~km} \mathrm{~h}^{-1}$ speed).

The baler used was brand New Holland, model BB9080, manufactured in 2013, with trailing coupling device and equipped with pickup feeding system (3 forks and 9 fingers), collector $225 \mathrm{~cm}$ wide, plunger stroke of $710 \mathrm{~mm}$ and 42 strokes per minute, double mooring system with 6 yarns per mooring and capacity of 30 yarn rolls, and bales produced in prismatic geometry, of dimensions $1.2 \mathrm{~m} \times 2.5 \mathrm{~m} \times 0.9 \mathrm{~m}$. A wheel tractor (brand New Holland, model T7240) manufactured in 2013, with $4 \times 2$ front-wheel drive and $161.81 \mathrm{~kW}$ nominal power was used to pull the baler. The rake used to windrow the sugarcane trash on the soil surface was brand New Holland, model H5980, set with a 9 meter working width, and pulled by a wheel tractor (brand New Holland, model TL 75E) manufactured in 2012, with $4 \times 2$ front-wheel drive and nominal power of $55.93 \mathrm{~kW}$. 
The trash volume in the experimental area was $10.2 \mathrm{t} \mathrm{ha}^{-1}$, corresponding to the sixth mechanized harvest of sugarcane. This volume was determined three days after harvest with the aid of a template of $0.6 \mathrm{~m} \times 0.6 \mathrm{~m}$, in six random replicates in the experimental area, adapted from the methodology of Ripoli (1991). Trash water content was determined by a digital moisture meter (brand Lippel, model ProAgro 100), equipped with a $0.5 \mathrm{~m}$ long rod. The average trash water content was $13.5 \%$, obtained by the measurement of six trash samples, with approximately ten kilos each, collected randomly in the trash windrows and pressed by a hydraulic jack.

Each experimental plot contained ten $400 \mathrm{~m}$ long windrows, distanced 7 and $8 \mathrm{~m}$ apart in the treatments with 50 and $90 \%$ windrowed trash, respectively.

The bales produced had their amount of mineral impurity (soil), dry weight, and volume evaluated. To quantify the mineral impurity of bales, four samples of six bales were collected per treatment, and a cylindrical electric probe was used (Gomes, 2014). The collected samples were submitted to mineral impurity analysis by the muffle method (Brasil, 1983).

The dry mass of bales, determined in a mobile digital scale, disregarded mineral impurity and water content (Equation 1).

$\mathrm{DM}=\mathrm{TW}-\mathrm{WC}-\mathrm{I}$

Wherein: DM is the dry mass of the bale $(\mathrm{kg}), \mathrm{TW}$ is the total weight $(\mathrm{kg}), \mathrm{WC}$ is the water content $(\mathrm{kg})$, and $\mathrm{I}$ is the impurity of the bale (\% in TW; $\mathrm{kg}$ ).

Bale volume was determined by Equation 2.

$\mathrm{BV}=\mathrm{H} \times \mathrm{W} \times \mathrm{L}$

Wherein: BV is the volume of the bale $\left(\mathrm{m}^{3}\right), \mathrm{H}$ is the height of the bale $(\mathrm{m}), \mathrm{W}$ is the width of the bale $(\mathrm{m})$, and $L$ is the length of the bale $(m)$

Hourly fuel consumption (Hfc), given in $L^{-1}$, was determined by the methodology described by
Barbosa et al. (2008). The tractor tank was fully loaded at the beginning of each plot and replenished after the operation, at the end of plots, with the aid of a graduated cylinder with a precision of $0.001 \mathrm{~L}$. Consumption was determined by reading the fuel volume used for tank replenishment as a function of the time demanded for displacement in the plot, recorded with a digital timer with precision of $0.01 \mathrm{~s}$. A 10-m spacing between plots was used for the procedure and for equalizing the tractor/baler combination.

Operational field capacity (OFC), given by the ratio between the area (or production obtained) and the total time in which the mechanized assembly remained in the field, was calculated using Equation 3, as described by Mialhe (1974).

$\mathrm{OFC}=\mathrm{WA} / \mathrm{PT}$

Wherein: OFC is the operational field capacity $\left(\right.$ ha $\left.^{-1}\right)$, WA is the worked area (ha), and PT is the productive time of the tractor/baler combination (h).

The hourly $(\mathrm{HC})$ and operating $(\mathrm{OC})$ costs of baling were calculated for the tractor and baler, using the methodology proposed by Mialhe (1974). The following fixed costs were considered: depreciation (straight-line method), interest, shelter, insurance and taxes; in addition to the following variable costs: fuel, lubricants, labor, and maintenance. The equations used for the calculations are listed in Table 1. The initial acquisition value $(\mathrm{Vi})$ of the tractor and baler were considered as those paid by the plant, $R \$ 189,000.00$ and $R \$ 236,944.50$, respectively. The residual value $(\mathrm{Vr})$ was $30 \% \mathrm{IV}$. The useful life in years (UL) was considered as ten years or 10,000 hours for the tractor, and ten years or 5,000 hours for the baler, with 1000 hours of use per year $(\mathrm{N})$ for the tractor, and 500 hours of $\mathrm{N}$ for the baler, according to the parameters of ASAE D497.7 (ASABE, 2011).

Table 1 - Equations used for cost calculations, methodology proposed by Mialhe (1974).

\begin{tabular}{lcl}
\hline Item & Legend & \multicolumn{1}{c}{ Equation } \\
\hline Hourly cost $\left(R \$ h^{-1}\right)$ & $\mathrm{HC}$ & $\mathrm{HC}=\mathrm{FC}+\mathrm{VC}$ \\
Fixed cost $\left(\mathrm{R} \$ \mathrm{~h}^{-1}\right)$ & $\mathrm{FC}$ & $\mathrm{FC}=\mathrm{D}+\mathrm{I}+\mathrm{S}+\mathrm{T}+\mathrm{F}+\mathrm{L}+\mathrm{M}+\mathrm{MO}$ \\
Depreciation $\left(\mathrm{R} \$ \mathrm{~h}^{-1}\right)$ & $\mathrm{D}$ & $\mathrm{D}=[(\mathrm{Vi}-\mathrm{Vr}) / \mathrm{UL}] \times(1 / \mathrm{N})$ \\
Interest $\left(\mathrm{R} \$ \mathrm{~h}^{-1}\right)$ & $\mathrm{I}$ & $\mathrm{I}=[(\mathrm{Vi}+\mathrm{Vr}) / 2] \times \mathrm{Tj} \times(1 / \mathrm{N})$ \\
Shelter $\left(\mathrm{R} \$ \mathrm{~h}^{-1}\right)$ & $\mathrm{S}$ & $\mathrm{S}=[(\mathrm{Ta} / 100) \times \mathrm{Vi}] / \mathrm{N}$ \\
Insurance and taxes $\left(\mathrm{R} \$ \mathrm{~h}^{-1}\right)$ & $\mathrm{T}$ & $\mathrm{T}=[(\mathrm{Ts} / 100) \times \mathrm{Vi}] / \mathrm{N}$ \\
Variable costs $\left(\mathrm{R} \$ \mathrm{~h}^{-1}\right)$ & $\mathrm{VC}$ & $\mathrm{VC}=\mathrm{F}+\mathrm{L}+\mathrm{M}+\mathrm{MO}$ \\
Fuel $\left(\mathrm{R} \$ \mathrm{~h}^{-1}\right)$ & $\mathrm{F}$ & $\mathrm{F}=\mathrm{Hfc} \times \mathrm{PC}$ \\
Lubrificants $\left(\mathrm{R} \$ \mathrm{~h}^{-1}\right)$ & $\mathrm{L}$ & $\mathrm{L}=0,095 \times \mathrm{F}$ \\
Maintenance $\left(\mathrm{R} \$ \mathrm{~h}^{-1}\right)$ & $\mathrm{M}$ & $\mathrm{M}=[(\mathrm{Tm} / 100) \times \mathrm{Vi}] / \mathrm{N}$ \\
Labor $\left(\mathrm{R} \$ \mathrm{~h}^{-1}\right)$ & $\mathrm{MO}$ & $\mathrm{MO}=(\mathrm{So}+\mathrm{Sc}) / \mathrm{N}$ \\
Operating cost $\left(\mathrm{R} \$ \mathrm{ha}^{-1}\right)$ & $\mathrm{OC}$ & $\mathrm{OC}=\mathrm{HC} / \mathrm{OFC}$
\end{tabular}

HC: hourly cost; FC: fixed cost; VB: variable costs; D: depreciation; I: interest; S: shelter; T: insurance of taxes; F: fuel; L: lubrificants; M: maintenance; MO: labor; Vi: initial acquisition value; Vr: residual value; UL: useful life in years; N: hours of use per year; Tj: interest rate; Ta: shelter rate; Ts: insurance rate and taxes; Hfc: Hourly fuel consumption; Pc: price of diesel oil ; Tm: rate of maintenance; So: monthly salary of the operator; Sc: Social and accounting charges; OC: operating cost; OFC: Operational field capacity. 
The interest rate $(\mathrm{Tj})$ adopted for the calculations was $8.5 \%$ per year (BNDES, 2017). The rate of shelter, insurance and taxes $(T)$ was considered as Ta a Ts of $1 \%$ (Mialhe, 1974). The rate of maintenance (Tm) of the tractor and baler was $100 \%$ and $60 \%$, respectively (ASABE, 2011). The price of diesel oil (Pc) was $R \$ 2.89 \mathrm{~L}^{-1}$, and the monthly salary of the operator (So) $R \$ 1.800,00$, considering the values paid by the plant. Social and accounting charges (Sc) were stipulated in $70 \%$ So, and the working day was 8 hours daily in 26 days per month.

The cost per bale (BC), given in $\mathrm{R} \$$ per bale, was obtained by dividing the OC by the number of bales produced per hour (Bph). Economic efficiency was determined by the cost/benefit ratio, obtained by dividing the productivity in bales per hour by the total cost of production (Guiducci et al., 2012).

Statistical analysis of data on bale volume, bale mineral impurity, bale dry weight, operational field capacity, bales produced per hour, hourly fuel consumption, and fuel consumption per bale were subjected to normality test, and subsequently to analysis of variance, with means compared by the Tukey test at $5 \%$ error probability, as recommended by Pimentel-Gomes (1987), using the statistical software Assistat. The results of costs and economic efficiency were compared by descriptive statistics, since they were absolute values and without the possibility of repetition.

\section{Results and discussion}

The results of the analysis of variance and mean test for the volume and mineral impurity of the bales produced by the prismatic baler are shown in Table 2.

Table 2 - Analysis of variance and test of mean volume of bales $\left(\mathrm{m}^{3}\right)$ and mineral impurity $(\%)$ of bales.

\begin{tabular}{|c|c|c|c|}
\hline Causes of variation & Volume of bales & Mineral impurity & Dry mass of bale \\
\hline Bale volume (BV) & $0.000^{\text {ns }}$ & $0.620^{\mathrm{ns}}$ & $0.000^{\mathrm{ns}}$ \\
\hline Baler speed (BS) & $0.005^{\mathrm{ns}}$ & $1.200^{\text {ns }}$ & $0.005^{\mathrm{ns}}$ \\
\hline$B V * B S$ & $1.0^{\mathrm{ns}}$ & $71.19^{\star *}$ & $263.21^{* *}$ \\
\hline Treatment & Means $\left(m^{3}\right.$ per bale) & Means (\%) & Means (kg per bale) \\
\hline A1V1 & 2.58 & $4.87 \mathrm{a}$ & $446.35 \mathrm{a}$ \\
\hline A1V2 & 2.58 & $4.94 \mathrm{a}$ & $453.72 \mathrm{a}$ \\
\hline A2V1 & 2.59 & $5.47 \mathrm{~b}$ & $501.11 \mathrm{~b}$ \\
\hline A2V2 & 2.59 & $5.62 \mathrm{~b}$ & $503.55 \mathrm{~b}$ \\
\hline CV (\%) & 0.37 & 1.71 & 0.79 \\
\hline SMD & 0.019 & 0.188 & 7.858 \\
\hline
\end{tabular}

CV: coefficient of variation; SMD: significant minimum difference; ${ }^{\text {ns }}$ not significant; ${ }^{*}$ significant by $\mathrm{F}$ test $(\mathrm{p} \leq 0.01)$. Means followed by the same lowercase letters do not differ statistically by Tukey test $(p>0.05)$.

The volume of bales produced was similar between treatments, indicating that the baler produces bales with regular height, width, and length, regardless of windrowed trash volume and working speed. This result is of great importance to the transportation of bales to the industry, since the volume and uniform shape of bales makes it possible to optimize the fleet of trucks in terms of number, size, load capacity, and power, improving efficiency and transportation costs (Michelazzo \& Braunbeck, 2008).

Bale volume uniformity makes it possible to comply more easily with Resolution No. 211/06 of the National Traffic Council - CONTRAN, which restricts to freight vehicles traveling on public highways the maximum limits of $19.8 \mathrm{~m}$ in length, $2.60 \mathrm{~m}$ in width, $4.40 \mathrm{~m}$ in height, and 57 tonnes gross weight. Freight vehicles whose dimensions exceed the limits provided for in the resolution may only travel with special transit authorization, which may be granted on the basis of a combined total gross weight requirement of 74 tonnes or less, a minimum length of $25 \mathrm{~m}$ and maximum of $30 \mathrm{~m}$, transit from dawn to sunset at a maximum speed of 80 $\mathrm{km} \mathrm{h}^{-1}$ and in roads containing an additional lane for slow vehicles in segments with slope and length exceeding $5 \%$ and $600 \mathrm{~m}$, respectively. For the trans- portation of bales in compliance with the resolution, it becomes important to know the dimensions and weight of the bales produced by a baler.

Treatments A1V1 and A1V2 had the lowest amount of mineral impurity in the bales, not differing from each other. The higher impurity indices observed for treatments $\mathrm{A} 2 \mathrm{~V} 1$ and $\mathrm{A} 2 \mathrm{~V} 2$ also did not differ from each other. Possibly, the lowest impurity index is related to the lower trash volume, since in this condition the rake operates with the windrowing fingers distant from the soil, reducing the volume of mineral impurities (soil and stones) in the trash windrow. The discussion corroborates a study carried out by Guerra et al. (2013), when they describe that windrowed trash volume affects bale purity, with a higher percentage of impurity the higher the windrowed trash volume.

Santos \& Borém (2016) clarify that knowing the index of mineral impurities in the bales is important because these impurities trigger mechanical damages to the industry. Mineral impurities provide corrosion and abrasion in boilers and components such as extractor sets, milling rollers, suits, and cylinders during the industrial process of burning the raw material in the sugar and alcohol industry (Lima \& Ferraresi, 2010). According to Santos \& Borém (2016), the desired pa- 
rameter is bales reaching a maximum value of $2 \%$ mineral impurities. Although not close to this parameter, the impurity results obtained were lower than that found by Perea et al. (2012), who evaluated sugarcane management systems and used, among other machines, a baler with pickup feeding system, finding an average impurity of $8 \%$ in bales. In an experiment evaluating a BD940 prismatic baler in the Piracicaba region, Torrezan (2003) obtained average mineral impurity of $6.31 \%$ in bales. Differences in results can be explained by soil type and moisture, amount of trash on the surface, and baler configuration.

The results of the analysis of variance and mean test for the dry weight of the bales produced by the prismatic baler are shown in Table 2 .

Treatments A1V1 and A1V2 led to bales with lower dry weight, not differing from each other. Treatments A2V1 and A2V2, with higher dry weight, also did not differ from each other. This result probably occurred due to the windrowed trash volume, since the higher the windrowed trash volume, the greater the dry weight of bales, regardless of baler speed. Presumably, greater windrowed trash volume increases the material supply in the baler collection and compaction system, producing bales with higher dry weight. The obtained results are compatible with the usual ones in power cogeneration plants. According to CTC (2013), the dry weight of prismatic bales can range from 180 to $700 \mathrm{~kg} \mathrm{bale}^{-1}$.

In a comparative study of two sugarcane trash baling systems, Lemos et al. (2014) obtained $294 \mathrm{~kg}$ dry weight for prismatic bales. Canto et al. (2011), in turn, obtained bale weight values between 535.4 and 570.9 kg. Moreover, Lotjonen \& Paappanen (2013), baling spring grass with different balers, obtained a dry weight between 246.16 and $345.42 \mathrm{~kg}$ for prismatic bales. Martelli et al. (2015) obtained $319 \mathrm{~kg}$ dry weight per bale. The difference in results for bale dry weight in these studies can be justified by the different water contents in baled biomass, type of baled material, constructive characteristics, and baler configuration.

Bale dry weight is an important characteristic for the logistics of transportation to the industry, since bales with lower dry weight facilitate the loading operation, although raising the cost per ton of transported trash (Tieppo et al., 2014).

The results of the operational performance of the tractor/baler combination are shown in Table 3.

Table 3 - Analysis of variance and mean test for operational field capacity (OFC), bales produced per hour (Bph), hourly fuel consumption (Hfc) and fuel consumption per bale (FCB).

\begin{tabular}{|c|c|c|c|c|}
\hline Causes of variation & OFC & Bph & $\mathrm{HfC}$ & FCB \\
\hline Bale volume (BV) & $38.56^{\mathrm{ns}}$ & $61.03^{\text {ns }}$ & $0.531^{\mathrm{ns}}$ & $214.55^{\mathrm{ns}}$ \\
\hline Baler speed (BS) & $86.06^{\text {ns }}$ & $52.54^{\text {ns }}$ & $0.015^{\text {ns }}$ & $0.083^{\text {ns }}$ \\
\hline$B V * B S$ & $18.09^{* *}$ & $25.07^{* *}$ & $19.94^{* *}$ & $67.05^{\star *}$ \\
\hline Treatment & OFC $\left(h^{2} h^{-1}\right)$ & Bph $\left(\right.$ bales $\left.h^{-1}\right)$ & $\mathrm{Hfc}\left(\mathrm{L} \mathrm{h}^{-1}\right)$ & FCB (L per bale) \\
\hline A1V1 & $4.9 \mathrm{a}$ & $37.6 \mathrm{a}$ & $21.55 \mathrm{a}$ & $0.565 \mathrm{~b}$ \\
\hline A1V2 & $5.5 b$ & $41.0 \mathrm{a}$ & $23.23 b$ & $0.572 \mathrm{~b}$ \\
\hline A2V1 & $4.8 \mathrm{a}$ & $46.7 \mathrm{~b}$ & $21.98 \mathrm{a}$ & $0.475 \mathrm{a}$ \\
\hline $\mathrm{A} 2 \mathrm{~V} 2$ & $5.4 \mathrm{~b}$ & $51.2 \mathrm{~b}$ & $23.58 \mathrm{~b}$ & $0.457 \mathrm{a}$ \\
\hline CV (\%) & 3.07 & 6.64 & 1.93 & 2.82 \\
\hline SMD & 0.336 & 4.734 & 0.917 & 0.030 \\
\hline
\end{tabular}

CV: coefficient of variation; SMD: significant minimum difference; ns not significant; ${ }^{* *}$ significant by F test $(p \leq 0.01)$. Means followed by the same lowercase letters do not differ statistically by Tukey test $(p>0.05)$.

The results indicate a higher OFC for treatments $\mathrm{A} 1 \mathrm{~V} 2$ and $\mathrm{A} 2 \mathrm{~V} 2$ compared to A1V1 and A2V1. The working speed influenced OFC values, since higher or lower values were obtained with different windrowed trash volumes. These results corroborate with those obtained by Gomes et al. (2016), who evaluated two balers and obtained a OFC of 3.4 and $5.7 \mathrm{ha}^{-1}$ with a baler similar to that used in the present study, with 50 and $90 \%$ windrowed trash, respectively. Lemos et al. (2014), using a prismatic baler in an experiment carried out in Lençóis Paulista, found that its operational capacity was $2.23 \mathrm{ha} \mathrm{h}^{-1}$, lower than that found in this study. Factors such as trash water content, working speed, and windrowed trash volume may have contributed to the divergence of results.

Although OFC was higher for treatments that used higher working speeds, bale production per hour (Bph) was higher in treatments with higher windrowed trash volume ( $\mathrm{A} 2 \mathrm{~V} 1$ and $\mathrm{A} 2 \mathrm{~V} 2)$, regardless of the speed used. Lower trash volume increases the distance travelled by the baler, thus requiring more time to produce a bale, resulting in lower bale productivity per hour. By using a greater windrowed trash volume, the context is reversed: a lower distance is travelled, demanding less time to produce a bale, increasing the bale productivity per hour of the baler. Gomes et al. (2016) obtained a production of 50.5 bales per hour for $50 \%$ collected trash, and 37 bales per hour for $90 \%$ collected trash, a difference also justified by the trash volume collected. The results obtained are equivalent to those found by Marteli \& Bentini (2015), who obtained trash volumes between 40.9 and 45 bales $\mathrm{h}^{-1}$.

The hourly fuel consumption $(\mathrm{Hfc})$ was lower in treatments $\mathrm{A} 1 \mathrm{~V} 1$ and $\mathrm{A} 2 \mathrm{~V} 1$ compared to $\mathrm{A} 1 \mathrm{~V} 2$ and A2V2. The Hfc value relates to the possible increase or reduction of the required tractive force of the tractor as a function of the working speed. According to Fiorese et al. (2015), in general, in agricultural tractors, fuel 
consumption is higher when the engine reaches the rotation near the maximum power and with the throttle fully open, the consumption tending to decrease with decreased engine rotation. This fact possibly proves that the higher $\mathrm{Hfc}$ in treatments A1V2 and A2V2 occurred due to increased tractive force of the tractor; in addition, the hydraulic system and power take-off were more demanded due to the collecting mechanism and compacting plunger of the baler. Furlani et al. (2013) and Francetto et al. (2015) also describe the ratio of speed over hourly fuel consumption as a func- tion of increased tractive power requirement of the tractor/implement combination.

Fuel consumption per bale (FCB) was higher for treatments $\mathrm{A} 1 \mathrm{~V} 1$ and $\mathrm{A} 1 \mathrm{~V} 2$ compared to $\mathrm{A} 2 \mathrm{~V} 1$ and A2V2. These results are related to the number of bales produced per hour; thus, the Hfc of A1V1 and A1V2 was higher due to lower Bph, and the Hfc of A2V1 and A2V2 was lower due to higher Bph.

The hourly costs, operating costs, costs per bale, and economic efficiency of the baling operation are shown in Table 4.

Table 4 - Hourly costs (HC), operational (OC), per bale (BC) and economic efficiency of the baling operation.

\begin{tabular}{lcccc}
\hline Treatment & $\mathrm{HC}\left(\mathrm{R} \$ \mathrm{~h}^{-1}\right)$ & $\mathrm{OC}\left(\mathrm{R} \$ \mathrm{ha}^{-1}\right)$ & $\mathrm{BC}(\mathrm{R} \$$ per bale $)$ & Economic efficiency \\
\hline A1V1 & 274.17 & 55.95 & 7.92 & 0.13 \\
$\mathrm{~A} 1 \mathrm{~V} 2$ & 280.02 & 50.91 & 6.83 & 0.15 \\
$\mathrm{~A} 2 \mathrm{~V} 1$ & 275.67 & 57.43 & 5.90 & 0.17 \\
A2V2 & 281.23 & 52.08 & 5.49 & 0.18 \\
\hline
\end{tabular}

The lowest hourly cost $(\mathrm{HC})$ was obtained in treatment $A 1 \mathrm{~V} 1, \mathrm{R} \$ 274.17 \mathrm{~h}^{-1}$, and the highest in treatment $\mathrm{A} 2 \mathrm{~V} 2, \mathrm{R} \$ 281.23 \mathrm{~h}^{-1}$, a difference of $2.5 \%$. This result is justified in Table 2, where A1V1 demands lower Hfc. The highest operating cost (OC), $\mathrm{R} \$ 57.43$ $\mathrm{ha}^{-1}$, was observed in treatment $\mathrm{A} 2 \mathrm{~V} 1,12.8 \%$ higher than treatment $A 1 V 2$, whose OC was $R \$ 50.91 \mathrm{ha}^{-1}$. The higher and lower OC are associated with the OFC of the treatment, where the lower the OFC, the higher the OC, as observed for treatment $\mathrm{A} 2 \mathrm{~V} 1$, and the higher the OFC, the lower the OC, as in treatment A1V2. The cost per bale (BC) was lower in A2V2 and higher in $A 1 V 1, R \$ 5.49$ and $R \$ 7.92$ per bale, respectively. The CF of A2V2 was $44.2 \%$ lower because the Fph was higher, reducing the unit cost of the bale. In treatment $A 1 \mathrm{~V} 1$, the hourly production of bales was lower, burdening the CF.

Lemos et al. (2014) observed higher operating costs for prismatic baler, US\$27.04 ha-1 (approximately $R \$ 86.52 \mathrm{ha}^{-1}$ ), considering the twine used in the bale among the variable costs. Canto et al. (2011), evaluating two balers producing bales from forest biomass, found the lowest operating cost to be US\$ 113.40 ha $^{-1}$ (equivalent to $\mathrm{R} \$ 362.88 \mathrm{ha}^{-1}$ ). The higher cost is possibly due to the baler model and its working conditions and operational capacity. For the baling of sugarcane trash, Gomes et al. (2016) observed an operating cost of $\mathrm{R} \$ 50.69$ at a site with $50 \%$ collected trash, and $\mathrm{R} \$ 28.73$ at a site with $90 \%$ collected trash. They also found an hourly cost of $R \$ 175.40$ and $R \$$ 165.80 , and cost per bale of $R \$ 4.71$ and $R \$ 4.45$, respectively, for 50 and $90 \%$ collected material.

According to the absolute values of costs, the highest economic efficiency of the baling operation was obtained in treatment A2V2, indicating that the investments of the operation (understood as costs for the purpose of calculations) are better converted into baler productivity. Comparatively, A2V2 was $25.5 \%$ more economically efficient than A1V1. The higher economic efficiency of the baler means that for each $R \$ 1.00$ demanded in costs, there is a higher productivity in bales per unit of space or time when compared to treatments with lower efficiency. In addition, greater economic efficiency leads to the production of bales with lower unit cost.

Lemos et al. (2014) obtained an economic efficiency of 4.56 for prismatic balers, and concluded that the higher cost percentage is justified by the larger amount of baled biomass. The authors considered logistic components, technology, and other equipment, items that influence costs and economic efficiency.

\section{Conclusions}

Bale volume was not influenced by windrowed trash volume and baler speed.

Higher windrowed trash volume provided lower cost per bale and higher mineral impurity index and dry weight of bales.

Hourly fuel consumption and operational field capacity increased with increasing working speed.

Higher windrowed trash volume provided a greater number of bales produced per hour.

Higher economic efficiency is obtained with higher working speed and windrowed trash volume.

\section{References}

Andreotti M, Soria JE, Costa NR, Gameiro RA, Rebonatti MD (2015) Acumulo de nutrientes e decomposição do palhiço de cana em função de doses de vinhaça. Bioscience Journal 31(2):563-576.

ASABE (2011) American Society of Agricultural and Biological Engineers. Agricultural Machinery Management Data, Standard ASAE D497.7. ASABE Standards, St. Joseph. 8p.

Barbosa RL, Silva FM, Salvador N, Volpato CES (2008) Desempenho comparativo de motor de ciclo diesel utilizando diesel e misturas de biodiesel. Ciência e agrotecnologia 32(5):1588-1593. 
BNDES (2017) Banco Nacional do Desenvolvimento. Programa de Modernização da Frota de Tratores Agrícolas e Implementos Associados e Colheitadeiras Moderfrota. Disponível em: <http://www.bndes.gov.br/wps/portal/site/home/financiamento/produto/moderfrota> (Acesso em 26 jun 2017).

Brasil (1983) Análise de corretivos, fertilizantes e inoculantes métodos oficiais. LANARV. $104 \mathrm{p}$.

Canto JL, Klepac J, Rummer B, Savoie P, Seixas F (2011) Evaluation of two round baling systems for harvesting understory biomass. Biomass and bioenergy 35(5):2163-2170.

Embrapa (2013) Empresa Brasileira de Pesquisa Agropecuária. Sistema brasileiro de classificação de solos, Rio de Janeiro. 353p.

Ferreira Filho JBS, Horridge M (2014) Ethanol expansion and indirect land use change in Brazil. Land Use Policy 36:595-604.

Fiorese DA, Marasca I, Fernandes BB, Sandi J, Morelli-Ferreira F, Lanças KP (2015) Desempenho de três tratores agrícolas em ensaios de tração. Revista de Agricultura Neotropical 2(2):68-76.

Francetto TR, Alonço ADS, Bellé, MP, Franck CJ, Carpes DP (2015) Comportamento operacional de associações entre sulcadores e discos de corte para sistema de semeadura direta. Engenharia Agrícola 35(3):542-554.

Franco FN (2003) Alguns parâmetros de desempenho operacional de um sistema de recolhimento de palhiço de cana-de-açúcar (Saccharum spp.) a granel. Esalq (Tese de doutorado em Agronomia).

Furlani CEA, Canova R, Cavichioli FA, Bertronha RS, Silva RP (2013) Demanda energética por semeadoraadubadora em função da haste sulcadora na semeadura do milho. Revista Ceres 60(6):885-889.

Gomes ARA (2014) Desempenho operacional de duas enfardadoras de fardos prismáticos retangulares no palhiço de cana-de-açúcar. Unesp (Dissertação de mestrado em agronomia).

Gomes ARA, Correia TPS, Dias PP, Kato LH, Silva PRA (2016) Desempenho operacional e econômico de duas enfardadoras prismáticas de palhiço de cana-deaçúcar. Energia na Agricultura 31(3):207-214.

Guerra SPS, Denadai MS, Takitane IC (2013) Biomassa: enfardadoras cilíndricas ou prismáticas? Revista Agriworld 4(12):100-102.
Guiducci RCN, Lima Filho JR, Mota MM (2012) Viabilidade econômica de sistemas de produção agropecuários: metodologia e estudos de caso. Embrapa. 535p.

Lemos SV, Denadai MS, Guerra SPS, Esperancini MST, Bueno OC, Takitane IC (2014) Economic efficiency of two baling systems for sugarcane straw. Industrial Crops and Products 55:97-101.

Lima AC, Ferraresi VA (2010) Análise de resistência ao desgaste de revestimento duro aplicado por soldagem em facas picadoras de cana-de-açúcar. Soldagem \& Inspeção 15(2):94-102.

Lotjonen T, Paappanen T (2013) Bale density of reed canary grass spring harvest. Biomass and bioenergy 51:53-59.

Marques TA, Pinto LEV (2013) Energia da biomassa de cana-de-açúcar sob influência de hidrogel, cobertura vegetal e profundidade de plantio. Revista Brasileira de Engenharia Agrícola e Ambiental 17(6):680-685.

Martelli R, Bentini M (2015) Removal notice to "Harvest storage and handling of round and square bales of giant reed and switchgrass, an economic and technical evaluation. Biomass and bioenergy 73:67-76.

Mialhe LG (1974) Manual de Mecanização Agrícola. Agronômica Ceres. 301p.

Michelazzo MB, Braunbeck OA (2008) Analysis of six systems of trash recovery in mechanical harvesting of sugarcane. Revista Brasileira de Engenharia Agrícola e Ambiental 12(5):546-552.

MME/EPE (2017) Ministério de Minas e Energia. Balanço energético nacional 2017. Disponível em: $<$ http://www.epe.gov.br/sites-pt/publicacoes-dadosabertos/publicacoes/PublicacoesArquivos/publicacao46/topico-

81/S\%C3\%ADntese\%20do\%20Relat\%C3\%B3rio\%20 Final_2017_Web.pdf> (Acesso em 26 jun 2017).

Perea LA, Biaggioni MAM, Seraphim OJ (2012) Evaluation of methods of trashhandling in the sugarcane field and industrialization. Energia na Agricultura 27(1):89-108.

Pimentel-Gomes F (1987) Curso de estatística experimental. Nobel. 466p.

Ripoli MLC, Gamero CA (2007) Sugarcane crop residue: standardized test collec-tion with a cylindrical baler. Energia na Agricultura 22(1):75-93.

Ripoli TCC (1991) Utilização do material remanescente de colheita de cana-de-açúcar (Saccharum spp) - Equacionamento dos balanços energético e econômico. Esalq (Tese de livre-docência). 
Santos F, Borém A (2016) Cana-de-açúcar do plantio à colheita. UFV. 290p.

Santos F, Borém A, Caldas C (2012) Cana-de-açúcar: Bioenergia, açúcar e etanol - Tecnologias e perspectivas. UFV. 637p.

Steiner E, Scott J, Mintom PN, Winzer K (2011) An agr quorum sensing system that regulates granulose formation and sporulation in Clostridium acetobutylicum. Applied and Environmental Microbiology 78:1113$-1122$.

Tieppo RC, Andrea MCS, Gimenez LM, Romanelli TL (2014) Energy demand in sugarcane residue collection and transportation. CIGR Journal 1:52-58.
Torrezan HF (2003) Enleiramento e enfardamento prismático de palhiço de cana-de-açúcar: alguns parâmetros de desempenho operacional e eficiência energética. Esalq (Dissertação de mestrado em Agronomia).

UNICA (2011) União da Indústria de Cana-de-Açucar $2017 . \quad$ Disponível em: <http://www.unica.com.br/noticia/36120944920335416 218/tecnologia-do-ctc-para-recolher-palha-de-canabeneficia-bioeletricidade-e-etanol-celulosico/> (Acesso em 14 mai 2019). 